\title{
Percepcija duhovnosti vjeroučitelja laika u današnjem društvu
}

\author{
Kata s. Amabilis Jurić*
}

\begin{abstract}
Sažetak
U radu su opisane odrednice identiteta vjeroučitelja laika na temelju teorijske teološko-katehetske literature te navedeni pokazatelji dosadašnjih istraživanja na tom području. Sagledavanje pojma vjeroučiteljeva identiteta odnosi se na njegovu poziciju crkvenog poslanika i dionika hrvatskog školskog sustava u koji ulaze sadržaji katoličke vjere, religioznog odgoja i kulture. Kako bi se navedene odrednice mogle odjelotvoriti u odgojno-obrazovnom procesu, vjeroučitelja se promatra kao snažnu i duhovnu osobu koja autentičnim životom svjedoči vjeru i doseže zadana obrazovna postignuća u okviru nastave katoličkog vjeronauka. Kršćanska duhovnost u ovom radu predstavlja ishodište duhovnosti vjeroučitelja laika. Teorijska istraživanja sintetiziraju mnogostruke karakteristike vjeroučiteljeve duhovnosti, od kojih je primarna tzv. funkcionalna duhovnost (spiritualità funzionale) koja ga bitno određuje, a svojstvena je vjeroučiteljevoj službi u školi $i$ župnoj zajednici. Kvalitativno istraživanje provedeno metodom dubinskih intervjua, opisanih u ovom radu, te metodološki postupci transkripcije, redukcije i prikaza podataka omogućuju dublje razumijevanje percepcije vlastite duhovnosti vjeroučitelja laika u današnjem društvu. Navedeno kvalitativno istraživanje predstavlja iskorak u odnosu na dosadašnja istraživanja jer podatci dobiveni dubinskim intervjuom donose inovativne spoznaje o duhovnosti vjeroučitelja $u$ Republici Hrvatskoj.

Ključne riječi: vjeroučitelj laik, identitet, kršćanska duhovnost, funkcionalna duhovnost, kvalitativno istraživanje, dubinski intervju
\end{abstract}

\section{Uvod}

Duhovnost, kao i duhovni profil vjeroučitelja, postali su u novije vrijeme predmetom znanstvenih i stručnih teološko-katehetskih promišljanja i rasprava. U tom kontekstu duhovnost, kao integrativna sastavnica vjeroučiteljeve osobnosti, predstavlja temeljnu odrednicu i središnje mjesto njegova identiteta, što

* Dr. sc. Kata s. Amabilis Jurić, Katolički bogoslovni fakultet Sveučilišta u Zagrebu. Adresa: Vlaška 38, pp 432, 10001 Zagreb, Hrvatska. E-pošta: sestraamabilis@gmail.com 
je predmet elaboriranja prvog dijela rada. Doprinos znanstvenoj spoznaji daju također empirijska istraživanja o identitetu vjeroučitelja u Hrvatskoj i nekim europskim zemljama.

U radu se nadalje istražuju teorijske postavke opće kršćanske duhovnosti kao ishodišta vjeroučiteljeve duhovnosti. Osim toga navode se neka relevantna obilježja vjeroučiteljeve duhovnosti (čovjek duha, svjedočke vjere i Crkve) neophodna za ostvarenje duhovne dimenzije njegova identiteta. Kvalitativnim istraživanjem potvrđuje se relevantnost specifične, odnosno »funkcionalne « duhovnosti vjeroučitelja, koja je u službi njegova poziva i djelovanja, kako u školi tako i u župnoj zajednici, te se ukazuje na izazove $\mathrm{i}$ inicijalno stanje potreba vjeroučitelja u suvremenom odgojno-obrazovnom procesu u današnjem društvu. Prikaz i interpretacija kvalitativnog istraživanja rezultata rada oslanja se na percepciju i rast vjeroučiteljeve duhovnosti, autentičnu i svjedočku vjeru, samodisciplinu i život u istini, budnost i otvorenost za poticaje Duha Svetoga. Promišljanja i pokazatelji o obrađenoj temi daju iscrpnu sliku vjeroučiteljeve duhovnosti, koja može poslužiti kao smjernica za permanentno stručno duhovno usavršavanje vjeroučitelja laika.

\section{Duhovnost kao odrednica identiteta vjeroučitelja laika}

\subsection{Bitne dimenzije vjeroučiteljeva identiteta}

Iznimno važan događaj za pastoralno i katehetsko djelovanje Crkve u Hrvatskoj dogodio se uvođenjem katoličkoga vjeronauka u hrvatske škole u vrijeme demokratskih promjena potkraj 20 . stoljeća. ${ }^{1}$ Četvrtstoljetno razdoblje prisutnosti vjeronauka u školi obvezuje nas da, uz mjesto i ulogu katoličkoga vjeronauka u odgojno-obrazovnom sustavu u Hrvatskoj, sustavnije promišljamo i o identitetu suvremenog vjeroučitelja laika. Odrednicu identiteta vjeroučitelja laika u današnjem društvu važno je pozicionirati i objasniti prema ukupnosti fenomenologije pojma identiteta, koji obuhvaća odnos po kojem je u različitim okolnostima nešto jednako samo sebi, istovjetno sa samim sobom. U tom kontekstu identitet vjeroučitelja laika također obuhvaća ukupnost činjenica koje služe da se jedna osoba razlikuje od bilo koje druge. ${ }^{2} \mathrm{U}$ nizu rasprava profilirala su se dva temeljna pitanja: kakav oblik religijske nastave uvesti u obnovljeni hrvatski školski odgojno-obrazovni sustav te kakav nam profil vjeroučitelja treba za kvalitetno ostvarivanje vjerskoga odgoja i obrazovanja u školi. ${ }^{3}$ To nas navodi na razmišljanje da je Crkvi već u samim početcima bilo jasno da su oblik religijske

1 Usp. Ružica Razum, Vjeronauk između tradicije i znakova vremena. Suvremeni izazovi za religijskopedagošku i katehetsku teoriju i praksu, Glas Koncila, Zagreb, 2008; Ivica Pažin, Vjeronauk u školi. Izabrane teme, Đakovo, 2010.

2 Usp. Vladimir Anić i sur., Hrvatski enciklopedijski rječnik, Zagreb, 2002, s. v. Identičan/identitet.

3 Usp. Milan Šimunović, Kateheza. Prvenstvena zadaća Crkve. Identitet i perspektive hrvatske pokoncilske kateheze i katehetike. U obliku bilance, Zagreb, 2011, str. 212. 
nastave i profil vjeroučitelja nerazdvojivo povezani, te da će identitet i status katoličkog vjeronauka bitno utjecati i na identitet vjeroučitelja laika.

Kad smo kod određenja značenja pojma identiteta vjeroučitelja, L. Soravito ga definira kao "pastoralnog djelatnika koji, posjedujući osnovnu ljudsku i kršćansku zrelost te određenu pastoralnu stručnost, $\mathrm{u}$ ime crkvene zajednice kojoj pripada i po 'ovlaštenju' biskupa ili zastupnika, promiče i vodi sustavan i postupan itinerar kršćanskog odgoja za određenu skupinu naslovnika ${ }^{4}{ }^{4}$ Taj se izraz ponekad upotrebljava i za nastavnika religije u školama, kao što je slučaj u nekim europskim zemljama. ${ }^{5} \mathrm{U}$ ovom radu riječ je o hrvatskom vjeroučitelju laiku, muškarcu ili ženi, bilo da je vezan sakramentom ženidbe ili je slobodnog stanja, koji radi u predškolskim, odnosno osnovnoškolskim i srednjoškolskim ustanovama formalnog obrazovanja. ${ }^{6}$ Stručno-znanstvena literatura navodi ove sastavnice vjeroučiteljevog identiteta: osobne kompetencije, pedagoškodidaktičke i teološko-religijsko-pedagoške kompetencije. ${ }^{7}$ Nedvojbeno je da se one moraju promatrati u odnosu na glavnu svrhu vjeronauka u odgojno-obrazovnom prakseološkom procesu i sustavu, povrh toga valja uvažavati pedagošku i kulturološku vrijednost vjeronaučne nastave, sadržajnu specifičnost i izvornu metodiku vjeronauka kao odgojno-obrazovnog predmeta u školi.

Vjeroučiteljev identitet se nadalje sagledava kroz poziciju crkvenog poslanika (missio canonica), djelatnika Ministarstva znanosti obrazovanja i sporta te djelatnika škole, ${ }^{8}$ koji predstavlja temelj vjeronaučnoga odgojno-obrazovnog procesa, preko kojega posreduje sadržaje katoličke vjere, religioznog odgoja i kulture. Osim toga kršćanski identitet vjeroučitelja poprima oznake odrasle osobe s potpunom zrelošću u vjeri, a to se postiže u svjesnom opredjeljenju za Isusa Kista, odgovornoj pripadnosti Crkvi te sposobnosti integracije važnosti vjere za probleme suvremenog čovjeka i društva. ${ }^{9} \mathrm{U}$ tom duhu valja naglasiti da njegova osobnost i identitet počivaju na kršćanskoj teološkoj antropologiji i kao takvi su neodvojivi od poslanja u školi, Crkvi i društvu. ${ }^{10}$ Stoga možemo s pravom tvrditi da se vjeroučiteljeva duhovna dimenzija, kao integrativna sastavnica njegova

4 Lucio Soravito, Vjeroučitelj, Marko Pranjić (ur.), Religiozno-pedagoško katehetski leksikon, Zagreb, 1986, 794.

5 Usp. Flavio Pajer, Nastavnik religije, Marko Pranjić (ur.), Religiozno-pedagoško katehetski leksikon, 500-502.

6 Usp. Milan Šimunović, Permanentna izobrazba vjeroučitelja, Kateheza, 1998, 20, 3, 190-195.

7 Usp., Georg Hilger - Stephan Leimgruber - Hanz-Georg Ziebertz, Vjeronaučna didaktika. Priručnik za studij obrazovanje i posao, Zagreb, 2009, 166-177; Jadranka Garmaz - Kristina Vukušić, Neke značajke vjeroučiteljeve duhovnosti, Služba Božja, 2015, 55, 1, 90-92.

8 Usp. Valentina Blaženka Mandarić - Alojzije Hoblaj - Ružica Razum, Vjeronauk - izazov Crkvi i školi. Empirijsko istraživanje na području Zagrebačke nadbiskupije, Zagreb, 2011, 84-86.

9 Usp. Cesare Bissoli — Joseph Gewart (ur.), La formazione dei catechisti. Problemi di oggi per la catechesi di domani, Leumann (Torino) 1998, 60-63.

10 Usp. Valentina Blaženka Mandarić - Ružica Razum (ur.), Identitet kao odgojno-obrazovna vrednota. Zbornik radova s tribina Zajednički vidici, Zagreb, 2011. 
cjelokupnog odgojno-obrazovnog djelovanja (znati, znati činiti i biti) odnosi na njegovo biti, i kao takva predstavlja »dušu i korijen njegove profesionalnosti «. ${ }^{11}$

Da bi se sve navedene zadaće mogle ostvariti u aktualnoj društvenoj situaciji, potrebna je snažna duhovna i profesionalna osoba s dubokim kršćanskim iskustvom življenim na osobnoj razini, koja će svojim autentičnim životom i djelovanjem dosegnuti zadane ishode vjeronaučnog odgoja i obrazovanja.

\subsection{Empirijska istraživanja o identitetu vjeroučitelja}

Identitetom vjeroučitelja bavili su se tijekom povijesti teolozi, religiozni pedagozi i katehetičari. Dosadašnja empirijska istraživanja imaju snažno uporište u teorijskim postavkama i aktualnoj novijoj profesionalnoj stvarnosti hrvatskih vjeroučitelja. Prvo značajnije istraživanje inicirao je Marko Pranjić12 u okviru Katehetskog salezijanskog centra 1991./1992. o stavovima i mišljenjima srednjoškolskih ravnatelja i vjeroučitelja vezano uz sadržaj vjeronauka, o vjeronauku kao nastavnom predmetu, suodnosu vjeronauka i struke te ulozi obitelji i škole u vjerskom odgoju. Vrijednost navedenog istraživanja i dobiveni rezultati otvorili su prostor daljnjim istraživanjima na području katoličkog vjeronauka u školi. Njegov doprinos sastoji se u tome što je Crkva, unatoč ratnim okolnostima, na samom početku vodila brigu o vjeroučiteljevom identitetu i utvrđivanju položaja vjeronauka kao relevantnog nastavnog predmeta u Republici Hrvatskoj.

Znanstvenim projektom iz 2008. pod imenom Vjeronauk u hrvatskom školskom sustavu/Empirijsko istraživanje na području Zagrebačke nadbiskupije, došlo se do važnih pokazatelja o identitetu vjeroučitelja, vjeronauku u školskom sustavu i pedagoško-didaktičko-sadržajnoj impostaciji. Navedeno djelo predstavlja snažan doprinos razumijevanju identiteta vjeroučitelja i mjesta vjeronauka kao nastavnoga predmeta, te daje mnogostruke poticaje za daljnja istraživanja vjeronaučne nastave, doradbu vjeronaučnih udžbenika i usavršavanje procesa inicijalnog i trajnog odgoja i obrazovanja vjeroučitelja. ${ }^{13} \mathrm{~S}$ obzirom na duhovni identitet vjeroučitelja došlo se do spoznaja da je u središtu cjelokupnog odgoja i obrazovanja čovjek, a onaj koji sudjeluje u odgojno-obrazovnom procesu (između ostalog i vjeroučitelj), nije posrednik samo znanja i vještina, nego ponajprije treba biti svjedok ljudskosti, odnosno odgojitelj i prenositelj životnog kršćanskog iskustva. $^{14}$

Treće u nizu empirijskih istraživanja provedeno je kao dio širega istraživačkog projekta usmjerenog na promišljanje o procesu inicijalne formacije vjeroučitelja na području Zagrebačke nadbiskupije od prosinca 2008. do siječnja 2009. godine. Iz istraživanja proizlazi da se vjeroučitelji po završetku inicijalne forma-

11 Lucio Soravito, Insegnante di religione: un'identità in fi eri. Tra l'essere e il dover essere, un profilo spirituale spirituale, Religione e Scuola, 1986.-1987, 15, 6, 277.

12 Usp. Marko Pranjić, Vjeronaučni program za srednje škole. Rezultati istraživanja srednjoškolskih ravnatelja i vjeroučitelja grada Zagreba i okolice, Kateheza, 1992, 4, 9-22.

13 Usp. Mandarić i dr., Vjeronauk - izazov Crkvi i školi, str. 11 i 225.

14 Usp. Isto, str. 83-131. 
cije osjećaju »najviše teološki $(\mathrm{M}=3,43)$, a ponajmanje duhovno kompetentni $(\mathrm{M}=2,73) \ll{ }^{15}$ Također je potrebno istaknuti još jedan važan rezultat, a taj je činjenica da s jedne strane vjeroučitelji smatraju osobnu vjeru važnim čimbenikom vjeroučiteljeva identiteta, ${ }^{16}$ međutim, s druge strane ističu da se oni po završetku inicijalne formacije na nekom od visokih učilišta ne osjećaju dovoljno duhovno osposobljenima. ${ }^{17}$ Kada se radi o vrednovanju važnosti pojedinih kvaliteta kao i njihova utjecaja na identitet vjeroučitelja, zaključno možemo konstatirati da vjeroučitelji smatraju duboku osobnu vjeru kvalitetom koja u najvećoj mjeri utječe na njihov identitet. ${ }^{18}$

Ukazujući na neke od međunarodnih istraživanja, valja spomenuti da su primjerice u Italiji provedena tri različita istraživanja na nacionalnoj razini o formaciji vjeroučitelja. ${ }^{19}$ Sva tri istraživanja ukazuju na veliki interes vjeroučitelja za Biblijom, odnosno njezinim dubljim poznavanjem kroz biblijsko-teološko proučavanje. U Njemačkoj je također provedeno sustavno empirijsko istraživanje $\mathrm{s}$ teorijskim utemeljenjem, tzv. berlinski model, ${ }^{20}$ isključivo orijentiran na kompleksnost kompetencija. Trodimenzionalnost kompetencija prepoznatljiva je na ovim razinama: religiozno-znanstvenim znanjima/vještinama, religioznim značenjima i njihovim interpretacijama te religioznim participacijama i performansima. Osim navedenih, hvalevrijedno je spomenuti i istraživanje o školskom vjeronauku u Europi, koje je pokrenulo Vijeće europskih biskupskih konferencija na poticaj i uz podršku Talijanske biskupske konferencije, ${ }^{21} \mathrm{u}$ kojem je sudjelovala i Hrvatska biskupska konferencija. U završnom dokumentu istaknuta su neka nezaobilazna područja za promišljanje o identitetu vjeroučitelja. ${ }^{22}$ Primjerice, kada se govori o profesionalnim i svjedočkim kompetencijama, istaknuto je da je Crkva u Europi posebnu pozornost posvetila odabiranju, formiranju i stalnomu usavršavanju vjeroučitelja, pružajući im posebnu duhovnu pratnju i trajne putove formacije. U tom se kontekstu primjećuje potreba za udruženjima vjeroučitelja

15 Usp. Denis Barić, Inicijalna formacija vjeroučitelja: Izazov Crkvi i školi, Obnovljeni život, 2013, $68,344$.

16 Denis Barić, L'insegnante di religione cattolica in un contesto di cambiamenti socio-religiosi. Ricerca empirica sulla formazione degli Insegnanti di religione cattolica nell'Arcidiocesi di Zagabria in Croazia, Roma, 2010, 63.

17 Usp. Denis Barić, Inicijalna formacija vjeroučitelja: izazov Crkvi i školi, str. 350.

18 Usp. Denis Barić, Obilježja identiteta vjeroučitelja u Zagrebačkoj nadbiskupiji, Bogoslovska smotra, 2013, 83, 2, 229.

19 Usp. Lucio Soravito - Cesare Bissoli, I catechisti in Italia: Identità e formazione, Leumann (To), 1983; Le religiose catechiste in Italia. Servizio e formazione. Indagine su 7.450 religiose impegnate nella katechesi, Supplemento alla rivista Consacrazione e Servizio, 1991, 40, 1; Giuseppe Morante, I catechisti parrocchiali in Italia nei primi anni ž90, Leumann (Torino), 1996.

20 Usp. Dietrich Benner - Rolf Schieder, Henning Schluß - Joachim Willems (Hrsg.), Religiöse Kompetenz als Teil pädagogischer Bildung. Versuch einer empirisch, bildungstheoretisch und religionspädagogisch ausgewiesenen Konstruktion religiöser Dimensionen und Anspruchniveaus. Paderborn, 2011.

21 Usp. Conferenza episcopale italiana. Servizio nazionale per l'IRC (ur.), L'insegnamento della religione - risorsa per l'Europa, Torino, 2008.

22 Usp. Vjeronauk - resurs za Europu. Sažetak i perspektive, Katehetski glasnik, 2009, 7, 1, 112117. 
na kojima bi se moglo, među ostalim, razgovarati i o temama njihove duhovnosti i profesionalnosti. ${ }^{23}$

Provedena istraživanja, empirijski pokazatelji te interes za temu duhovnog identiteta vjeroučitelja u Europi i Hrvatskoj podloga su za daljnja istraživanja na temelju kojih bi se vjeronaučna nastava i metodički pristup osuvremenio u skladu s duhovno-vjerničkim potrebama i vrednotama današnjega postmodernoga društva.

\section{Kršćanska duhovnost - ishodište vjeroučiteljeve duhovnosti}

\subsection{Opća kršćanska duhovnost}

Kada promišljamo o kršćanskoj duhovnosti, važno je naglasiti da se nakon Drugog vatikanskoga sabora javlja pojačan interes i veliko zanimanje za njezino proučavanje, tim više što je Sabor pozvao sve vjernike na svetost. ${ }^{24}$ Time pitanje duhovnosti zauzima relevantnu poziciju i to u tolikoj mjeri da ju se svrstava $\mathrm{u}$ znakove vremena koji upućuju na istinsku potrebu suvremenog čovjeka i svijeta. ${ }^{25}$ Neovisno o tome je li riječ o kršćanskom životu, odnosno o proživljenom kršćanskom iskustvu, ili o znanstvenoj disciplini koja se bavi tim predmetom, treba istaknuti trostruko usmjerenje kršćanke duhovnosti. Ona se isključivo bavi ljudskom osobom, potom se usredotočuje na cjelokupni spektar onih stvarnosti koje sačinjavaju kršćanski život u odnosu prema Bogu. Naposljetku, predmet proučavanja kršćanske duhovnosti u poslijekoncilskom vremenu daleko je širi nego što je to bilo prije Koncila, o čemu svjedoče i mnogi znanstveni izvori. ${ }^{26}$ Otuda i očekivanje da oni koji se bave kršćanskom duhovnošću budu otvoreni dostignućima drugih disciplina, koje itekako svojim bogatim spoznajama mogu poslužiti kao izvor rasta i razvitka u kršćanskom životu. ${ }^{27}$

Utemeljenje i razumijevanje kršćanske duhovnosti vidljivo je u teološkim načelima koja, primjerice, T. Matulić28 izvodi iz teologije duhovnosti, što posljedično upotpunjuje i naša promišljanja o duhovnosti vjeroučitelja laika. U tom kontekstu sa sigurnošću možemo tvrditi da je kršćanska duhovnost u samom svojem izvoru teocentrična, iz razloga što se ravna logikom Božjega kraljevstva, pneumatocentrična, jer je određena logikom Božje ljubavi koja je »razlivena u srcima

23 Usp. Isto, 115.

24 Usp. Drugi vatikanski koncil, Lumen gentium. Dogmatska konstitucija o Crkvi, Zagreb, 72008, br. 40.

25 Usp. Marko Ivan Rupnik, U vatri gorućeg grma. Uvođenje u duhovni život, Split, 2006, str. 8.

26 Usp. Michael Downey, Duhovnost kršćanska, u: Suvremena katolička enciklopedija (ur. Michael Glazier i Monika K. Hellwig), Split, 1998, str. 223.

27 Usp. Anton Bucher, Psychologie der Spiritualität, Basel, 2007; Benedict J. Groeschel, Psihologija duhovnoga razvoja, Split, 2009; Stipe Tadić, Religiozno iskustvo — neistraživana i/ili neistraživa dimenzija religije i religioznosti, Društvena istraživanja, 1998, 7, 3, 359-373.

28 Usp. Tonči Matulić, Metamorfoze kulture. Teološko prepoznavanje znakova vremena u ozračju znanstveno-tehničke civilizacije, Zagreb, 22009, 842-843. 
našim po Duhu Svetomu koji nam je dan!«(Rim 5, 5). Nadalje, kršćanska duhovnost je bitno kršćanska po tome što glavni motiv svojega oživotvorenja pronalazi u osobi Isusa Krista, odnosno svojoj kristocentričnoj usmjerenosti. Upravo zato duhovnost pretpostavlja konkretno i egzistencijalno iskustvo živoga i zauzetoga Boga u povijesti Isusa Krista, odakle joj i dolazi ime. ${ }^{29}$ Stoga se jasno nameće konstatacija da je poziv vjeroučitelja laika temeljen prije svega na biti kršćanin, oblikovan Duhom Svetim, tako da je njegov život u samoj biti označen dubokom prethodno opisanom kršćanskom duhovnošću.

\subsection{Relevantna obilježja duhovnosti vjeroučitelja}

U prilog relevantnosti teme duhovnosti vjeroučitelja laika govori činjenica da su teološko-katehetska i religiozno-pedagoška promišljanja iznjedrila nekoliko važnih modela, među kojima razlikujemo funkcionalni, ${ }^{30}$ biblijski, ${ }^{31}$ kristocentrično-eklezijalni, ${ }^{32}$ praktični ${ }^{33}$ i evangelizacijski model. ${ }^{34} \mathrm{U}$ ovom dijelu rada kratko ćemo se usredotočiti na bit funkcionalnog modela, koji na najizričitiji način govori o duhovnosti vjeroučitelja laika kao specifičnoj odrednici njegova poziva i djelovanja u školi i kršćanskoj zajednici. Francuski teolog i katehetičar Joseph Colomb, autor poznatog katehetskog priručnika $U$ službi vjere, jedini tvrdi da postoji specifična, tzv. funkcionalna (spiritualità funzionale) duhovnost vjeroučitelja laika, kao primjerice benediktinska, franjevačka, isusovačka i sl. S obzirom na to da je Božja riječ, među ostalim, temeljni sadržaj vjerskog odgoja i obrazovanja, Colomb u svojem elaboratu ističe dva bitna elementa duhovnosti vjeroučitelja: u funkciji Poruke koju naviješta ${ }^{35}$ i u službi ljudi koji slušaju Poruku, ${ }^{36}$ unutar teologalnih kreposti vjere, nade i ljubavi. Iz ostalih navedenih modela, kao i promišljanja hrvatskih znanstvenika na tom području, proizlaze mnogostruka obilježja i karakteristike vjeroučiteljeve duhovnosti. Zbog tematske širine u ovom radu usredotočit ćemo se samo na neke od njih, one bez kojih je nezamislivo ostvarenje vjeroučiteljske službe.

\subsubsection{Vjeroučitelj — čovjek duha}

Katekizam Katoličke Crkve uči nas da je ljudska osoba, ukoliko je stvorena na sliku Božju, u isti mah tjelesno i duhovno biće. ${ }^{37} \mathrm{U}$ tom kontekstu vjeroučitelja

29 Usp. Isto, 843-844.

30 Usp. Joseph Colomb, Al servizio della fede. Manuale di catechetica, Torino, ${ }^{2} 1970,745-766$.

31 Usp. Cesare Bissoli, La formazione spirituale del catechista, Istituto di catechetica - UPS (ur.), Formare i catechisti in Italia negli anni 80, Torino, 1982, 55-63.

32 Usp. Piergiorgio Brodoloni, Il ministero e la spiritualità del catechista, Roma, 1990.

33 Usp. Pietro Damu, La spiritualità del catechista. Tracce per la riflessione personale e di gruppo sui tratti che la caratterizzano, Torino, 1996.

34 Giancarla Barbon - Rinaldo Paganelli, Annunciare a partire dal Cuore. Una spiritualità per $i$ catechisti, Bologna, 1998.

35 Usp. Joseph Colomb, Al servizio della fede, str. 749-756.

36 Usp. Isto, str. 756-762.

37 Katekizam Katoličke Crkve, Zagreb, 1994, br. 362. 
treba shvatiti kao duhovnu osobu, čovjeka duha, koji dobro prepoznaje vrednote odozgo, sretan što mu »Bog nije dao duha bojažljivosti, nego snage, ljubavi i razbora $(2$ Tim 1,7$)$. Biti duhovan znači biti antrophos pneumaticos, prožet snagom Božjom, čije su riječi, geste, stavovi, sva njegova nastojanja odraz plodova Duha koje nabraja apostol Pavao u Poslanici Galaćanima (usp. Gal 5, 22-23). ${ }^{38}$

Apostolska pobudnica Catechesi Tradendae u zaključku Duha Svetoga predstavlja kao unutarnjeg Učitelja, koji u tajnosti savjesti i srca čini da vjeroučitelj razumije ono što je čuo, a nije bio u stanju sam razumjeti. Otuda proizlazi važnost aspekta nutarnjeg poučavanja koje je duboko, cjelovito i konstantno, te kao takvo omogućuje primjereno razumijevanje Kristova otajstva u prošlosti, sadašnjosti i budućnosti. ${ }^{39}$ Papa Ivan Pavao II. smatrao je da suvremeni vjeroučitelj, kao čovjek duha, treba vidjeti Nevidljivoga i iznutra se sjediniti s Božjom apsolutnom veličinom. Upravo iz takvog sjedinjenja on će moći autentično svjedočiti, jer će mladi i odrasli govoriti o onom što su vidjeli, tj. ono uza što prianjaju cjelovitošću svoje osobe. ${ }^{40}$ Komentirajući navedeni tekst Apostolske pobudnice, P. Damu tvrdi da vjeroučitelj treba postajati sve više svjestan činjenice da svojim djelovanjem živi kao poslušni instrument Duha Svetoga, iz čega proizlazi odgovornost da tog istog Duha stalno priziva, bude s njime ujedinjen i neprestano se trudi upoznati njegove najdublje inspiracije. ${ }^{41}$ Navedene konstatacije potvrđuje i papa Pavao VI. kada ističe da »bez Duha ništa ne vrijedi ni najsvetija priprava navjestitelja. I najuvjerljivija oštroumnost bez njega je pred ljudskim duhom bespomoćna. Sve psihološke i sociološke do u tančine razrađene sheme bez njega se ubrzo pokazuju bezvrijednima «. ${ }^{42} \mathrm{Na}$ temelju svega izloženoga sada bolje razumijemo tvrdnju naših biskupa da prava formacija za vjeroučiteljski poziv neophodno treba uključivati i odgoj za otvorenost Duhu Isusa Krista, za prihvaćanje njegovih poticaja i za oslanjanje na njegovo vodstvo. ${ }^{43}$

\subsection{2. Čovjek svjedočke vjere}

Kao odgovor na potrebe ljudi koji su duhovno gladni u našem društvenokulturnom okruženju od vjeroučitelja se očekuje ne samo da bude dobar poznavatelj teoloških sadržaja, nego i čovjek žive, istinske i svjedočke vjere, »uvjerljivo uvjereni vjernik «, čiji je poziv i djelovanje sušta suprotnost »vjerskomu službeniku «. ${ }^{44}$ Poučavajući svjedočki vjeronauk u školi, vjeroučitelj na konkre-

38 Ante Mateljan, Identitet katoličkog vjeroučitelja. Temelj kompetencije i osnova suradnje, Kateheza, 2003, 25, 2, 94-95.

39 Ivan Pavao II, Catechesi Tradendae. Apostolska pobudnica biskupima, svećenicima i vjernicima cijele Crkve o vjerskoj pouci u naše vrijeme, Zagreb 1994, br. 72.

40 Usp. Tomislav Ivančić, Vjeroučitelj izazov hrvatskom društvu, Zagreb, 2010, 48.

41 Usp. Pietro Damu, La Spiritualità del catechista, str. 148.

42 Papa Pavao VI, Evangelii nuntiandi. Apostolski nagovor o evangelizaciji u suvremenom svijetu, Zagreb, 1976, br. 75 .

43 Usp. Hrvatska biskupska konferencija, Na svetost pozvani. Pastoralne smjernice na početku trećeg tisućljeća, Zagreb, 2002, br. 21.

44 Usp. Špiro Marasović, Lik vjeroučitelja za treće tisućljeće, Kateheza, 1998, 20, 1, 10-11. 
tan način pokazuje učenicima kako će suvremeno društvo prožeti kršćanskim vrednotama, čime postaje vidljivim znakom kršćanske poruke, tj. evanđelja. ${ }^{45}$ Vjeroučiteljevo svjedočko zvanje pretpostavlja kršćansko vjerničko iskustvo, ${ }^{46}$ koje se stječe svakodnevnim uranjanjem u otajstvo Božje riječi, ${ }^{47}$ aktivnim sudjelovanjem u liturgijsko-sakramentalnim događajima našega spasenja te u njegovanju kršćanske molitve, ${ }^{48} \mathrm{u}$ koje vjeroučitelj uvodi svoje vjeroučenike i tako im pomaže da u svjetlu evanđeoskih perspektiva traže odgovore na svoja temeljna životna pitanja. ${ }^{49}$ Vjeroučitelj nije svjedok samoga sebe, nego je svjedok Kristova iskustva koje se živi u zajednici vjernika, tj. Crkvi. Slijedom rečenoga proizlazi da vjeroučitelji posreduju daleko više po onom što jesu, nego po onom što govore. Stoga tvrdi J. Baloban da se ne može ni zamisliti da vjeroučitelj u školi nije uvjereni praktični vjernik..$^{50}$

\subsection{3. Čovjek Crkve}

Vjeroučitelj je primarno čovjek Crkve, koja mu kanonskim poslanjem omogućuje da svojom osobnom vjerom u potpunosti sudjeluje u vjeri te iste Crkve. Dakako da se bez duhovne jakosti i pravog duha crkvenosti neće moći suprotstaviti brojnim suvremenim izazovima, kao što su sekularizam i karijerizam, ili da u Crkvi vidi neku svoju ekonomsku i političku računicu, svojstvenu »crkvenomu namješteniku «.51 Nasuprot tomu od njega se očekuje da osluškuje poticaje Duha Svetoga i djeluje prema njegovim nadahnućima, izgrađuje krepost vjere, kojom prihvaća Boga, nade, po kojoj se u Boga uzda, i ljubavi, po kojoj se s Bogom sjedinjuje. Također, vjeroučitelj treba u sebi razvijati eklezijanu svijest da je poslan od Crkve na primjeren način podsjećati vjeroučenike da nema cjelovitog rasta u vjeri bez uključivanja u vjersku zajednicu, u kojoj se Božjom riječju i sakramentima događa cjeloviti susret s Isusom Kristom u zajedništvu s drugima. ${ }^{52} \mathrm{~S}$ druge strane, kao »predstavnik Crkve « školski vjeroučitelj osobnim potencijalom proročkog i kritičkog iskustva kršćanske vjere postaje nadahniteljem i izvorom djelovanja u izgradnji ljudskog projekta škole, ispunjavajući njezine odgojno-obrazovne zadaće. 53

45 Usp. Jadranka Garmaz — Kristina Vukušić, Neke značajke vjeroučiteljeve duhovnosti, 94 i 97.

46 Usp. Nediljko A. Ančić, - Nikola Bižaca (ur.), Iskustvo vjere danas. Zbornik radova teološkog simpozija Split, 22. Listopada 1999, Split, 2000.

47 Usp. Tomislav Ivančić, Vjeroučitelj izazov hrvatskom društvu, 19-24; Tomislav Ivančić, Svjedočki vjeronauk, Kateheza, 1998, 20, 4, 307-316.

48 Usp. Jadranka Garmaz — Kristina Vukušić, Neke značajke vjeroučiteljeve duhovnosti, str. 99101.

49 Usp. Josip Baloban, Djelovanje Crkve u novim društvenim okolnostima, Zagreb, 1995, 89-90.

50 Usp. Isto, str. 89.

51 Usp. Špiro Marasović, Lik vjeroučitelja za treće tisućljeće, str. 10.

52 Usp. Jadranka Garmaz — Kristina Vukušić, Neke značajke vjeroučiteljeve duhovnosti, str. 96.

53 Usp. Jaques Schepens, Duhovnost vjeroučitelja, Kateheza, 2007, 29, 1, 56. 


\subsection{Prikaz i interpretacija rezultata kvalitativnog istraživanja}

Kvalitativno istraživanje, ${ }^{54}$ čiji su rezultati izloženi u ovome radu, provedeno je metodom nestandardiziranog (halbstrukturiertes-leitfadenorientiertes) dubinskog/narativnog intervjua, ${ }^{55}$ koja se u stručnoj literaturi pokazala najprimjerenijom na teološkom području. Cilj istraživanja bio je analizom empiričke deskripcije stvarnoga stanja prirode duhovnosti vjeroučitelja laika u službi u hrvatskom školstvu i komparacijom njezinih rezultata s idealnim konceptom utvrditi obujam slaganja, odnosno neslaganja, s vrhunskim obzorjem duhovnosti. ${ }^{56} \mathrm{U}$ istraživanju je sudjelovao 41 vjeroučitelj iz svih (nad)biskupija (24 u osnovnim i 17 u srednjim školama) s naznačenim demografskim pokazateljima. Kvalitativno istraživanje provodilo se od kolovoza do prosinca 2010. godine. Navedeni pokazatelji upućuju na to da je po prvi puta uzorak ispitanika obuhvatio cijelu Republiku Hrvatsku. Time se dobila sveobuhvatna informacija o duhovnosti vjeroučitelja laika, odnosno kako se i na koji način integrativna stvarnost njegove osobnosti/ identiteta odražava na odgojno-obrazovni proces i crkveno-društveni kontekst. Prikupljanje podataka i obrada sadržaja dobivenih temeljem dubinskih intervjua sadržavala je 10 općenitih pitanja svedenih na tri tematska područja. ${ }^{57}$ Analiza sadržaja ostvarena je korištenjem triju metodoloških postupaka: transkripcijom i redukcijom podataka, prikazivanjem podataka s posebnim naglaskom na zajedničkim i razlikovnim točkama te izvođenjem zaključaka. ${ }^{58}$ Interpretacija rezultata kvalitativnog istraživanja zahtijevala je i istraživača u tumačenju i dubljem razumijevanju istraživane tematike. Interpretacija također prati konceptualizaciju navedene teme duhovnosti vjeroučitelja laika. ${ }^{59}$

\subsubsection{Percepcija vjeroučiteljeve duhovnosti}

$\mathrm{Na}$ temelju dobivenih rezultata kvalitativnog istraživanja možemo ustvrditi da intervjuirani vjeroučitelji percipiraju svoju duhovnost kao općekršćansku datost zajedničku svim kršćanima. Svi ispitanici duhovnost smatraju posebnom kategorijom, koja proizlazi iz njihovog ljudsko-kršćansko-vjerničkoga života i službe koju vrše kanonskim poslanjem u hrvatskoj školi. Time, sukladno teološko-katehetskoj literaturi, potvrđuju da je riječ o specifičnoj, tzv. funkcionalnoj duhovnosti vjeroučitelja, na temelju koje oni kao laici vrše posebnu službu u školi i župnoj zajednici.

54 Usp. Siegfried Lamnek, Qualitative Sozialforschung: Lehrbuch, Beltz, 2005, 21-30.

55 Usp. Marlene Bock, Das halbstrukturierte-leitfadenorientierte Tiefeninterview: Theorie und Praxis der Methode am Beispiel von Paarinterviews, u: Jürgen H. Hoffmeyer-Zlonik, Analyse verbaler Daten. Über den Umgang mit qualitativen Daten, 1992, 90-109; Goran Milas, Istraživačke metode u psihologiji i drugim društvenim znanostima, Zagreb, 22009., 571-589.

56 Usp. Kata s. Amabilis Jurić, Duhovnost vjeroučitelja laika u Hrvatskoj, Zagreb, 2015, 242.

57 Usp. Isto, 240-242.

58 Usp. Goran Milas, Istraživačke metode u psihologiji i drugim društvenim znanostima, 601-608.

59 Usp. Isto, 575. 


\subsubsection{Rast u duhovnosti}

Rast i napredovanje u individualnoj duhovnosti vjeroučitelja laika u navedenom istraživanju ispitanici smatraju procesom koji se ostvaruje tijekom cjeloživotnoga obrazovanja i stručnoga usavršavanja. Pri tom su navodili neke važne elemente kao što su trajni rad na sebi, što uključuje disciplinu, sabranost, šutnju i meditaciju, komunitarnu dimenziju, razumijevanje težine obiteljske situacije i sl. Mogućnost rasta i napredovanja u duhovnosti realiziraju prakticiranjem molitvenog i sakramentalnog života, čitanjem i meditiranjem Božje riječi, duhovnih vježbi i obnova te raznih vrsta seminara primjerenih specifičnim potrebama vjeroučiteljske duhovnosti. Intervjuirani vjeroučitelji prepoznaju svakodnevnu molitvu kao privilegirano mjesto u kojem stječu unutarnju snagu koja potiče duhovni rast i preobrazbu njihova života i djelovanja. Vjeroučitelji mlađe životne dobi (od 2 do 9 godina radnog staža) navode ove razloge za usporeni rast u duhovnosti: osobnu mlakost, lijenost i pomanjkanje vremena i samodiscipline te smatraju da bi trebali još više raditi na sebi, oslobađajući se kompleksa manje vrijednosti, neprihvaćenosti, pomanjkanja povjerenja u sebe i u druge te više poraditi na stavu poniznosti, prevladavanju krive slike o Bogu i sl. Također ističu i potrebu za iskrenošću prema sebi i drugima, strpljivošću, slobodom, većom fleksibilnošću i otvorenošću stvaralačkim poticajima Duha Svetoga. Vjeroučitelji s dužim radnim iskustvom (od 10 do 19 godina radnog staža) nemaju istovrsne izričaje kao mlađi kolege. Oni se bore s opasnošću formalizma u rastu duhovnoga života te predlažu promicanje zajedničke specifične duhovnosti vjeroučitelja putem duhovnih vježbi te obnova u šutnji i sabranosti pod vodstvom stručno osposobljenih osoba. Objedinjeno je mišljenje vjeroučitelja mlađe i starije životne dobi da je gotovo nemoguce rasti i napredovati u vjeroučiteljskom pozivu i poslanju bez duhovnog voditelja (pratitelja). ${ }^{60}$ Nadalje, nedostatak istinskog zajedništva, otvorenosti i povjerenja zajednička je konstatacija koja ozbiljno ugrožava njihov duhovni rast i napredovanje u duhovnom životu i radu.

\subsubsection{Autentična i svjedočka vjera}

Autentična i svjedočka vjera prepoznata je u rezultatima kvalitativnog istraživanja kao najvažnija karakteristika vjeroučiteljeve duhovnosti, koja proizlazi iz prisnog odnosa s Kristom, iz kojeg se rađa postojanost i vjernost svojemu pozivu i poslanju u hrvatskoj školi. Stoga gotovo svi ispitanici ne vide boljeg načina od autentične i svjedočke vjere, kao odgovora na izazove vremena u kojem žive i djeluju. Da je tomu tako, najbolje potvrđuje jedan od ispitanika koji upozorava na opasnosti sekulariziranog društva bez duha, a time i bez Boga, u kojemu je suvremeni vjeroučitelj pozvan dati razlog nade koja je u njemu: »Meni se čini da idemo k Zapadu i zapadnom društvu, koje se sve više razvodnjava i sekularizira, a nama vjeroučiteljima treba snaga tog svjedočenja da bismo mogli sve to izdr-

60 Franz Jalics, Miteinander im Glauben wachsen. Anleitung zum geistlichen Begleitgespräch, Würzburg, 2008; Daniel Burke - John Bartunek, Upravljanje nutarnjim životom. Duhovno vodstvo $i$ putovanje Bogu, Zagreb, 2014. 
žati... Stoga vjeroučitelj u školi nije samo prosječni prosvjetni djelatnik, niti jednostavno samo član Crkve, nego je on taj most između Crkve i svijeta, taj vidljivi znak, živi svjedok onoga što živi i naučava u konkretnim crkvenim i društvenim prilikama «. ${ }^{61}$ Svjedočku dimenziju vjere ispitanici povezuju s visokim obrazovanjem vjeroučitelja laika, ali ipak daju prednost svjedocima vjere prvih generacija vjeroučitelja, koji su svojim entuzijazmom bili uključeni u nastavu uvođenjem vjeronauka u hrvatske škole.

\subsubsection{Samodisciplina $i$ život u istini}

Smjernicu samodiscipline i života u istini vjeroučitelji smatraju neophodnom za svoju duhovnost, ali i kao odgovor na suvremene izazove društva i vremena u kojem žive. Ta se tvrdnja primarno odnosi na ispitanike mlađe životne dobi, jer samodisciplina i osobni rad na duhovnoj razini bitno određuju njihov duhovni identitet. Stoga smatraju potrebnim boraviti u školi Krista Učitelja i svakodnevno učiti od njega, u kome je izvor sve mudrosti i znanja, te time svestrano njegovati svoju duhovnost. Vrijedno je izdvojiti mišljenje mlade vjeroučiteljice koja naglašava važnost iskrenosti kao vrhunske kvalitete za sve one vjeroučitelje koji žele napredovati u školi Kristove istine: »od mene se traži svjedočanstvo života, a ne mogu svjedočiti ako sam u laži«. ${ }^{2}$ Također i ispitanici starije životne dobi potvrđuju neophodnost osobnog rada na duhovnoj razini kroz samodisciplinu i život u istini, dodajući pritom da poslušnost Učitelju u životu i istini za sobom povlači isti taj odnos prema autoritetu Crkve, zaposlenicima škole, župnoj zajednici te vjeroučenicima kojima su poslani služiti.

\subsubsection{Budnost i otvorenost za poticaje Duha Svetoga}

Osobni odnos s Isusom Kristom postiže se razmatranjem i meditacijom Duhom Svetim nadahnute Božje riječi, jer svi su intervjuirani vjeroučitelji duboko svjesni činjenice da je njihovo pripremati teren i sijati, a Isus je taj koji daje da sjeme raste i na kraju donosi plodove (usp. 1 Kor 3, 6-9). U tom smislu ispitanici kvalitativnog istraživanja, bilo mlađe ili starije životne dobi, svoj poziv i djelovanje u školi i župnoj zajednici vide u stanju trajne budnosti i otvorenosti novim traženjima i otkrivanjima, koja se događaju u sili i snazi Duha Svetoga. Zaključno možemo utvrditi da su gotovo svi intervjuirani vjeroučitelji duboko svjesni činjenice kako bez trajne otvorenosti poticajima Duha Svetoga nema promjene života u njima samima, a ni u njihovim vjeroučenicima, jer »Duh Sveti djeluje u svakom blagovjesniku koji mu se prepusti da ga vodi i da u njegova usta stavi do čega on sam ne bi mogao doći, dok u isto vrijeme pripravlja i dušu slušatelja da bude otvorena i prijemčiva za radosnu vijest i Kraljevstvo koje se naviješta ${ }^{63}$

61 Kata s. Amabilis Jurić, Duhovnost vjeroučitelja laika u Hrvatskoj, str. 352.

62 Isto, 351.

63 Pavao VI., Evangelii nuntiandi, 1976, br. 75. 


\section{Zaključak}

Prikazujući i opisujući relevantne rezultate dobivene istraživanjem o percepciji duhovnosti vjeroučitelja laika u današnjem društvu, nastojalo se ukazati na promišljanja kompetentnih stručnjaka o nekim odrednicama vjeroučiteljeva identiteta u teorijskim i empirijskim istraživanjima. Uvidom u rezultate istraživanja došlo se do zaključka da se o duhovnosti vjeroučitelja laika unutar odgojnoobrazovnog sustava treba promišljati kao o integrativnoj sastavnici njegova identiteta. Istraživanja potvrđuju činjenicu da je opća kršćanska duhovnost ishodište duhovnosti vjeroučitelja laika, s time da je riječ o posebnoj, tzv. funkcionalnoj duhovnosti, koja je u službi njegova poziva i djelovanja u hrvatskom obrazovnom sustavu. Pojam vjeroučiteljeve duhovnosti kao bitne odrednice identiteta pronalazimo u nekim empirijskim istraživanjima koja su elaborirana u ovom radu. Uvidom u njihove rezultate kao zaključak valja istaknuti da vjeroučitelji među ponuđenim kvalitetama duboku osobnu vjeru smatraju iznimno važnim čimbenikom njihova identiteta. Međutim, isti ti vjeroučitelji, po završetku inicijalne formacije, ne osjećaju se u dostatnoj mjeri duhovno osposobljenima za ispunjenje svoga poslanja. Analizom dubinskih intervjua obrađenih u kvalitativnom istraživanju u Republici Hrvatskoj došlo se do pokazatelja koji predstavljaju korpus vjeroučiteljevih iskaza (unutarnjeg monologa) otjelotvorenog u dijalogu s istraživačem. Prikupljeni iskazi vrijedno su blago skrivene duhovne intime intervjuiranih vjeroučitelja, koja vapi za podrškom i potporom ili pak može biti čvrsti oslonac za dobru i kvalitetnu nastavu katoličkoga vjeronauka. Unatoč navedenim pokazateljima i pomacima na duhovnoj razini, rezultati kvalitativnog istraživanja ukazuju na diskrepanciju, odnosno nepodudarnost s proklamiranim idealnim duhovnim profilom vjeroučitelja. Unutarnji stavovi intervjuiranih vjeroučitelja i prikupljeni iskazi ispitanika podloga su za daljnja istraživanja o duhovnosti vjeroučitelja kako bismo toj temi dali epistemološki doprinos.

Rezultati ukupnih istraživanja u radu obuhvaćaju odrednice identiteta vjeroučitelja laika te njegove duhovne dimenzije, koju u perspektivi valja dalje istraživati kako bismo utvrdili koncept, odnosno hrvatski model duhovnosti vjeroučitelja u skladu s postojećom društvenom situacijom i odgojno-obrazovnim potrebama suvremenog hrvatskog obrazovnog sustava. 


\section{The Lay Catechist's Spirituality as Perceived by Society Today}

Kata s. Amabilis Jurić*

\section{Summary}

The article describes the determinants of the lay catechist's identity based on theoretical theological-catechetical literature. Also cited are indicators of research done up to the present time in this area. This approach to the concept of the catechist's identity pertains to his position as an emissary of the Church and participant in the Croatian school system into which content of the Catholic faith, religious upbringing and culture have gained entrance. In order that the cited determinants may be applied in the education process, the catechist is regarded as a strong and spiritual person whose authentic life is a testimony of faith and who accomplishes educational tasks within the framework of Catholic catechism class. Christian spirituality represents in this article the fountainhead of the lay catechist's spirituality. Theoretical research synthesizes the manifold characteristics of the catechist's spirituality among which the primary characteristic is functional spirituality, or 'spiritualità funzionale' as it is called, and which essentially determines the person, as well as being inherent in the catechist's ministry both in the school and parish community. Qualitative research carried out by means of the in-depth interview method as described in this essay, and also methodological procedures such as transcription, reduction and presentation of data make possible a deeper understanding of the lay catechist's spirituality as perceived by society today. The above-mentioned qualitative research represents a departure from research done up until now because data gained through the in-depth interview conveys innovative knowledge regarding the Croatian catechist's spirituality in the Republic of Croatia.

Key words: lay catechist, identity, Christian spirituality, 'functional' spirituality, qualitative research, in-depth interviews

* Kata s. Amabilis Jurić, Ph.D., The Catholic Faculty of Theology, The University of Zagreb. Adress: Vlaška 38, pp 432, 10001 Zagreb, Croatia. E-mail: sestraamabilis@gmail.com 